\title{
An information system infrastructure and applications for improving white collar productivity in a steel manufacturing works
}

H. Morihisa*, H. Ikeda*, H. Uchibori*, R. Oshita*, and N. Komoda**

*Nippon Steel Information \& Communication Systems (Ins. (ENICOM)),

** Department of Information Systems Engineering, Faculty of Engineering, Osaka University

*1,Fuji-cho,Hirohata-ku Himeji, Hyogo, 671-1188 Japan

Phone +81-792-36-8423, Fax +81-792-37-2011

hmorihis@hhh.osk.enicom.co.jp,

hikeda@hhh.osk.enicom.co.jp, huchibor@hhh.osk.enicom.co.jp, roshita@hhh.osk.enicom.co.jp

**2-1 Yamadaoka, Suita, Osaka 565-0871 Japan

Phone +81-6-879-7825, Fax +81-6-879-7827

komoda@ise.eng.osaka-u.ac.jp

\begin{abstract}
In the Japanese Steel Industries, computers were applied to the manufacturing planning in the middle of 1970's and afterwards the total information systems of the steel plant in the field of manufacturing management have been developed. In consequence, productivity in the field of manufacturing has been improved. Furthermore, recently, the white-collar productivity in the field of management has been recognized as a major problem to be solved to cope with the international competition. In this paper, we propose the concept, its applications and
\end{abstract}


infrastructure of information systems to improve their productivity. These days, as a result of decision making down-sizing, the problem-solving approach of white collar staff will be changed from the legacy "deterministic approach" to the "biological approach", in which we solve problems by way of iterative hypotheses and verifications. We propose one-stop-shopping and seamless information systems which are distributed on the main information LAN in the works and suitable for white collar activities. In order to realize this concept, we constructed the FDDI local area network and developed some applications which make use of multi-media data such as bitmap images and photos.

\section{Keywords}

local area network, FDDI, multi-media, one-stop-shopping and seamless, manufacturing management, white collar productivity, information system, biological approach

\section{INTRODUCTION}

Nippon Steel's Hirohata Works first introduced computers for production planning and scheduling in around 1965 and has since developed the integrated information systems by introducing computers to all levels of production control within the Works. These main systems, mainly, operation control system, contributed greatly to the improvement of productivity of the Works, producing various effects.

In more recent years, the improvement of productivity of the clerical and administrative organizations has become increasingly important to improve international competitiveness. As the productivity of white-collar employees is not labor-intensive, the improvement of their productivity lies in how their jobs can be improved or renovated in an effective and creative manner. The role of the information system is to back up such improvement or renovation. In this sense, the development of information system which contributes to the improvement of productivity of white-collar employees at steelworks has become important. The present paper describes how the information system (information system in a broad sense, including the planning support system at the steelworks) should be built under a consistent philosophy, citing concrete examples.

\section{PROBLEMS IN THE MANAGEMENT OF STEELWORKS AND MEASURES TAKEN FOR SOLUTION}

\subsection{Background of the development of information system and features of the system}

The features of activities in the steel industry are as follows:

- Order-based production system 
- Utilization of trading firm's functions for distribution

- Total integrated management system, centering around steelworks

- Long and diversified processes from the raw materials stage to end products

- All manufacturing processes and the transportation processes connecting these manufacturing processes with each other are batch processes. The production lot becomes progressively smaller in the direction of downstream processes and close through-process control is required.

- Non-stop 24-hour operation

Since the 1960s, the steel industry has developed the information systems which are fully geared to the features of the activities described above.

In the 1960s, the development of batch control system and then on-line integrated steelworks management system which run nonstop for 24 hours throughout the year was started in step with the development of general-purpose computer.

In the 1970 s, the enlargement of general-purpose computer and the stabilization of computer technology urged the start of development of integrated production control system, building of process computer systems for controlling the operations of plants, such as rolling mill plant, in the steelworks and their interconnections to meet the needs of those days for cost reduction through manpower saving and energy conservation.

In the 1980s, effort was directed, for example, toward the development of systems, such as order entry system linking the steel company with trading firms, aiming at the improvement of non-price competitiveness for the improvement of operation efficiency, strengthening of sales competitiveness or price differentiation, and the building of systems, such as total material flow control system, aiming at further personnel retrenchment.

In the 1990s, the development of strategic information system, aiming at the systematization of major activities, the systematization of engineering business, and the rebuilding of systems for system cost reduction were started.

In addition, the systems utilizing the advantages of the man-machine interface realized by shifting the characters terminals to graphics terminals and the planning and diagnosis systems utilizing the AI method were developed in response to the widespread acceptance of workstation and personal computer.

The company's major activities are covered by these information systems, producing remarkable results through stabilized operations (Ito,1992 and Furukawa,1991).

In recent years, the situation that confronts the steel industry has been changing, making it necessary to respond to new problems. The problems in the management of the steel industry are described in the next section. 


\subsection{Problems and measures taken for their solution}

Users' steel product purchasing strategy is changing. Namely, recent trend is toward the simplification of manufacturing specifications for steel products and the diversification of steel product supply sources, including purchase from Asian countries. To meet these trends, it is necessary for the Japanese steel industry to further improve its international competitiveness on a dollar basis (Osada ,1993).

The Japanese steel industry has been taking the following measures to meet these problems.

(1) Improvement of the international competitiveness of white-collar employees

To preserve international competitiveness, it is necessary to change the type of organization of staff divisions to improve their productivity in addition to the improvement of productivity of the manufacturing divisions which is now reaching the limit. In other words, the downsizing of decision-making through the reduction in the number of managerial classes and in the number of white-collar employees to an elite corps is necessary. The speed of management to respond to changes in business climate and the accuracy of decision can be improved through such downsizing.

Examples of the reduction in the number of managerial classes in the world are shown in Table 1.

Table 1. Transition of the number of managerial classes in the world

\begin{tabular}{|l|c|c|l|}
\hline Company & $\begin{array}{c}\text { Number of } \\
\text { Old } \\
\text { Hierarchy }\end{array}$ & $\begin{array}{c}\text { Number of New } \\
\text { Hierarchy }\end{array}$ & \multicolumn{1}{|c|}{ Hierarchy } \\
\hline POSCO & $6 \sim 10$ & 3 & $\begin{array}{l}\text { Executive Committee } \\
\text { Department Manager } \\
\text { Team Leader }\end{array}$ \\
\hline National Steel & 8 & 4 & $\begin{array}{l}\text { President } \\
\text { Vice President } \\
\text { General Manager } \\
\text { Manager }\end{array}$ \\
\hline $\begin{array}{l}\text { Nippon Steel } \\
\text { Corporation }\end{array}$ & 7 & 4 & $\begin{array}{l}\text { Executive Committee Director } \\
\text { General Manager } \\
\text { Group Leader }\end{array}$ \\
\hline
\end{tabular}

(2) Mini-mill type business management

Hitherto, the steelworks has been a division specializing in manufacture. In the future, however, the steelworks will be required to run its business in a compact, slimmed down and integrated manner as a small company, covering materials purchase and sales in addition to production. 
To realize such a flat organization and mini-mill type management, the conventional decision-making method must be improved. Namely, the information transfer method, judgment information level and decision-making method must be improved. The improvements to be made are summarized in Table 2.

Table 2. The functions for improvements to be made

\begin{tabular}{|c|c|c|}
\hline Item & Previous Method & Functions for Improvements \\
\hline $\begin{array}{l}\text { Communica- } \\
\text { tions Media }\end{array}$ & Conference + Telephone & Effective Communications \\
\hline $\begin{array}{l}\text { Information } \\
\text { for Decision } \\
\text { Making }\end{array}$ & $\begin{array}{l}\text { Data Stored in each } \\
\text { Application System }+ \\
\text { Document of the Data }\end{array}$ & $\begin{array}{l}\text { Standardized Business Structure } \\
\text { Storing Data Cooperatively } \\
\text { Flexible Retrieval }\end{array}$ \\
\hline $\begin{array}{l}\text { Decision } \\
\text { Making }\end{array}$ & $\begin{array}{l}\text { Explanation of Prepared } \\
\text { Draft }+ \\
\text { Process of Obtaining } \\
\text { Sanction of Executives }\end{array}$ & $\begin{array}{l}\text { Effective Collaboration } \\
\text { Flexible and Prompt Judgement Based on } \\
\text { Evaluation of Case Study }\end{array}$ \\
\hline
\end{tabular}

\section{INFORMATION SYSTEM BASED ON NEW CONCEPT}

\subsection{Basic concept}

In the conventional hierarchical organization, decision-making is limited to top management only. In recent years, the down-sizing of decision-making has become widespread as a result of the flattening of organizational hierarchy. In this type of decision making, each white-collar employee must make a decision rapidly. For this purpose, each employee must perform multiple jobs at the same time and the information system must be designed to back up each employee.

On the other hand, approach to the solution of problems in the job area of white-collar employees will be changed from the so-called "deterministic approach", in which the methodology for solving problems is determined, to the "biological approach" in which problem setting and the methodology for solution are not determined but an appropriate solution is obtained by repeating hypothesizing and verification (Shimizu, 1990).

Fig. 1 shows an image of business evolution by the hypothesis and verification type biological approach. The hypothesis and verification type approach for problem solving is described below (Ito and Saka,1995). 


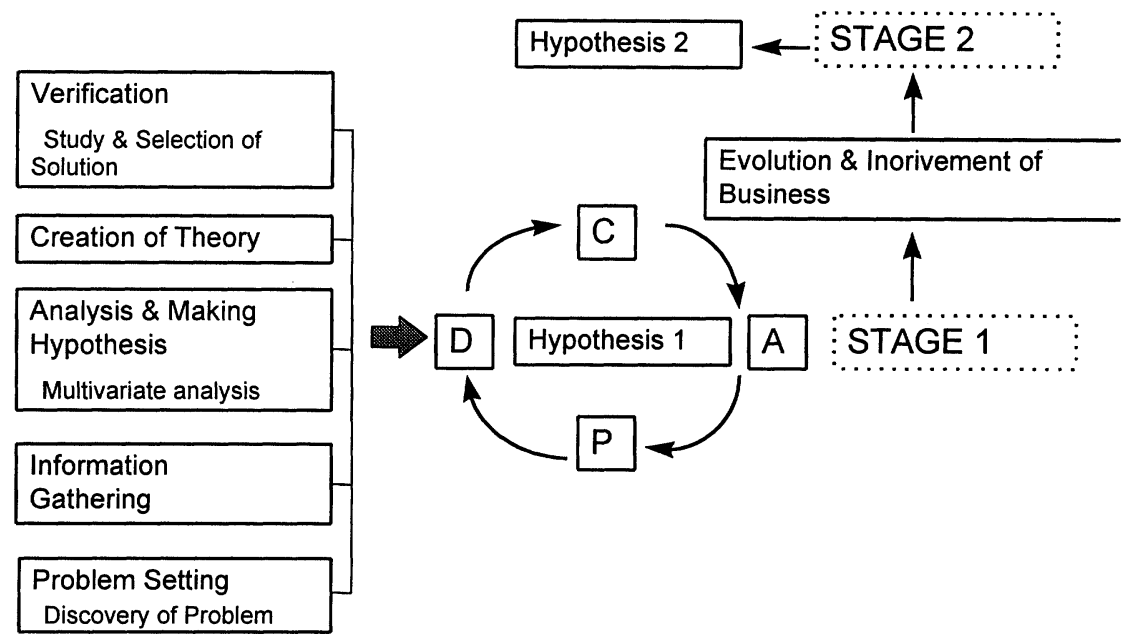

Fig.1 An image of business evolution by the hypothesis and verification type biological approach

- Problem setting: The problem or subject to be solved is identified or found out.

- Information gathering: Information is collected.

- Analysis and making of hypothesis: A hypothesis is made based on the results of information analysis.

- Creation of theory: A theory is created. The problem in question is explained or a solution is worked out by creating the hypothesis in one's own way.

- Verification: The created theory or solution is verified through simulation, experiment or practice.

- Evolution: The hypothesis or theory is improved many times until the best answer is obtained.

\subsection{Concepts underlying the development of information system for supporting the hypothesis and verification type approach}

The important concepts underlying the development of information system for supporting the hypothesis and verification type approach described in the preceding section are outlined below.

(1) Consolidation of tasks through integration of information

The tasks which have hitherto been carried out through multiple functional organizations are simplified by using the shared data base and information processing function. 
For this purpose, it is necessary to create a class library for steelmaking business by analyzing the data. Based on this class library, the production results and know-how are accumulated. Moreover, the accumulated information base (results \& know-how data base) is effectively created.

\section{(2) Accumulation of raw data}

In the past, for example, the individual data was individually processed and a stereotyped decision was made. It has become necessary to change this environment so that a decision is made based on the results of a variety of analysis.

For such analysis and decision, the raw data collected at a point close the data generation source is required instead of processed data.

Table 3 shows a comparison between the data base storing preprocessed data and the source data base in which raw data is accumulated (ledger system).

Table 3. A comparison between the data base storing preprocessed data and the source data base

\begin{tabular}{|c|c|c|}
\hline & $\begin{array}{l}\text { Data Base Storing } \\
\text { Preprocessed Data }\end{array}$ & Source Data Base \\
\hline $\begin{array}{l}\text { Feature of Stored } \\
\text { Data }\end{array}$ & $\begin{array}{l}\text { *Preprocessed Data } \\
* \text { Poor in Contents }\end{array}$ & $\begin{array}{l}\text { *Raw Data } \\
\text { *Rich in Contents }\end{array}$ \\
\hline $\begin{array}{l}\text { Feature } \\
\text { of Computer } \\
\text { Structure }\end{array}$ & $\begin{array}{l}{ }^{*} \text { High Price Data Base } \\
\text { Engine for Public Use }\end{array}$ & $\begin{array}{l}\text { *Low Price Data Base Engine for } \\
\text { Private Use \{Man-Machine } \\
\text { Interface } \\
{ }^{*} \mathrm{DB}+\mathrm{NW}+\mathrm{PC}\end{array}$ \\
\hline Utility & $\begin{array}{l}\text { *Regular and One-sided } \\
\text { Analysis }\end{array}$ & *Many-sided Analysis \\
\hline
\end{tabular}

(3) Improvement of information gathering capacity of individual employees and establishment of job system in which such capacity is fully utilized (Do it yourself)

In the past, routine tasks were carried out by using the common terminals. When the improvement of a system was required, a request was made to the division specializing in system development to develop a desired system or modify the existing system. As the business improvement cycle has been shortened in recent years, however, the following have become necessary:

- Improvement or renovation of one's own job by oneself

- Daily operation by one's own division itself

For this purpose, the terminal environment customized for each employee becomes necessary so that each employee can freely handle the required information. In addition, an organization which offers training, consulting and support for troubleshooting at any time required is necessary to allow the full use of such terminals.

(4) Job linkage by utilizing the information network

The information accumulated on the network in a decentralized manner must be fetched smoothly by utilizing the individual terminals which are linked with each 
other on the network. In other words, the one-stop-shopping-seamless \& communication (OSSSC) function is required.

In short, such a system is required in which each person can perform his job using the terminal allocated to him personally (one-stop-shopping) instead of using the conventional common terminal and the new findings or information obtained from each job can be readily communicated seamlessly in an integrated manner without data conversion between the information systems which supporting each job.

OSSSC is a digitally integrated network linkage. Namely, the gathering, processing, and analysis and evaluation of information as well as consultation and settlement and instruction exchange among the persons concerned are backed up in an integrated manner.

So far, the general concept of the following information system which is based on a new biological concept and contributes to the improvement of productivity of white-collar employees has been described.

- Quick response by a flexible system supporting creativity and downsizing of decision-making

- Evolution and improvement of jobs in a spiral manner through shortening of business improvement cycle and rotation of PDCA circle

- Digital integration of information to enable the use of required information on demand

Table 4. The key words required for realizing the new information system

\begin{tabular}{|c|c|c|}
\hline & Old Key Words & New Key Words \\
\hline $\begin{array}{l}\text { Business } \\
\text { Structure }\end{array}$ & $\begin{array}{l}\text { *Plan Oriented } \\
\text { *Hierarchical Orders }\end{array}$ & $\begin{array}{l}\text { *Down-sizing of Decision Making } \\
\text { *Flat Organization }\end{array}$ \\
\hline $\begin{array}{l}\text { Information } \\
\text { Structure }\end{array}$ & $\begin{array}{l}\text { *Master File and } \\
\text { Preprocessed Data File for one } \\
\text { Purpose } \\
\text { *Data Processing in eac } \\
\text { Application System }\end{array}$ & $\begin{array}{l}\text { *Sharing of Information } \\
\text { *Many-sided View } \\
\text { *Facility of Acquiring and } \\
\text { *Processing Information } \\
\text { *Do it your self }\end{array}$ \\
\hline $\begin{array}{l}\text { Implementation } \\
\text { Structure }\end{array}$ & $\begin{array}{l}\text { *Basing on Mainframe } \\
\text { Computer } \\
\text { *Special-purpose Terminal }\end{array}$ & $\begin{array}{l}\text { *Equipment of Information System } \\
\text { Infrastructure } \\
\text { :Network } \\
\text { :Distributed Data Base } \\
\text { :One Computer per Person } \\
\text { *Information Literacy Education }\end{array}$ \\
\hline
\end{tabular}

The key words required for realizing the new information system are summarized in Table 4. 
Examples of the hypothesis and evaluation type information system developed on the basis of the biological approach at steelworks are described below.

The rebuilding of infrastructure on which the information system is based is first described, followed by the information technology support center established for the improvement of information literacy to enable all employees to fully utilize the infrastructure.

Now, the respective concrete examples are described. First, the prompt production result reporting system developed for early detection of the problem as the starting point of the hypothesis and verification type information system is described. Then, the decentralized type total technology control system and NTCS (New Total Communication System) which are the means of supporting the collection of information necessary for hypothesis and verification are described. Finally, the hypothesis and verification type planning system for multiple lines is introduced.

\subsection{Rebuilding of information system infrastructure}

(1) Needs of rebuilding

Needs of rebuilding the managerial information system infrastructure are shown below.

- white collar staff need to use both operational systems and managerial systems through their personal computer.

- they need to handling various kind of data such as production result data, plant scheduling planning data and managerial data at the same time.

- they need to utilize their favorite package software such as a statistical analyzing software.

(2) The architecture of the new network system

At that time, the Sigma network(Hitachi product) had been equipped in the Hirohata steelworks. The overall maximum transfer speed from host computer to the computer terminals is limited to $19.2 \mathrm{kbps}$ because of the limitation of the performance of the installed $\mathrm{CCP}$ (communication control processor). And the available protocol on the network was limited to HNA which is the proprietary Hitachi protocol. In this network infrastructure, the information activities were limited because of the lack of the openness. Or we could not use multi-media information and PC. Therefore, we decided to rebuild the information system infrastructure.

The $f^{\circ}$ network had been utilized for both the operational field and the managerial information field. And the managerial information network infrastructure was separated from the operational information network in order to 
upgrade the information infrastructure for the managerial information systems. We utilized the existing optical-fiber cable and built the managerial information LAN based on the international standard FDDI and TCP/IP protocol could be made to be used in order to make use of personal computers instead of the proprietary expensive terminals. As a results, the high-speed(100Mbps) LAN was built and the distributed and open network environment where we could use global standard hardware and software was made to be available.

The nodes and the servers were distributed at every sections in steel works. The ethernet network systems were also built for the white collar staffs.

The architecture of the new network systems is shown in Fig2.

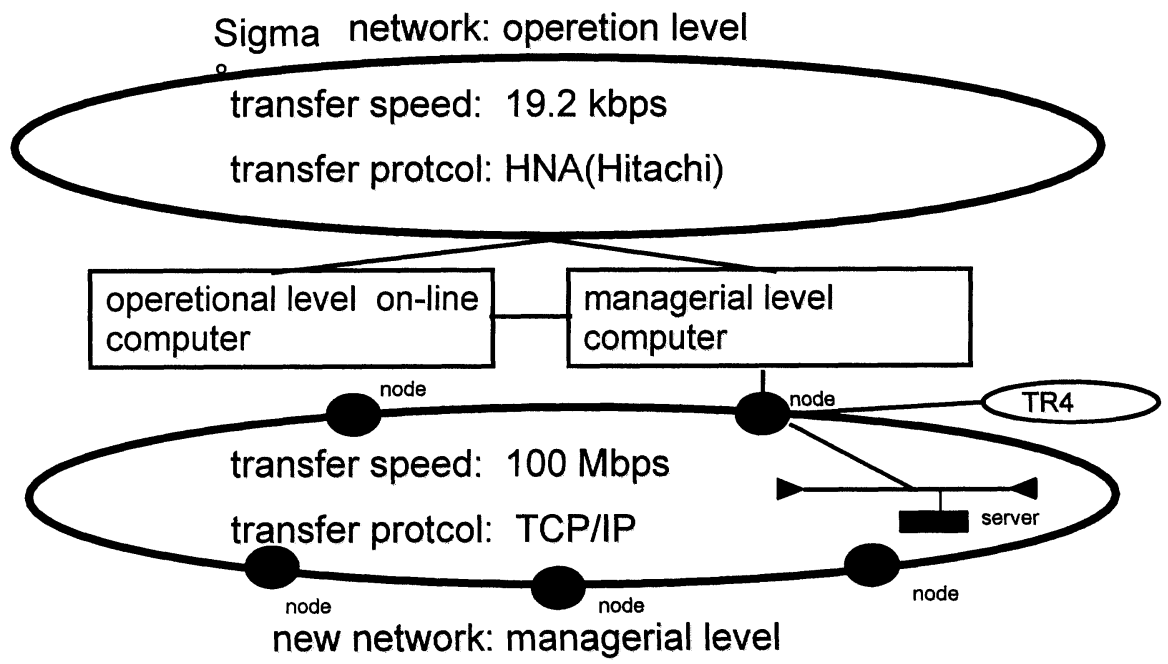

Fig.2 The architecture of networks

(3) The result of rebuilding

The information system infrastructure was rebuilt by developing the information system network environment (main LAN for information system) within the steelworks to change the conventional system built on a large frame. On this network, one each personal computer was distributed to each person in managerial position. "One computer per person" was promoted by distributing the computer to management first so that the persons in managerial position realize the advantages of computer by experience. They can also use on-line systems and Time Sharing systems through their personal computers with the aid of XNF(Hitachi TCP/IP support software for main-frame computer). 


\subsection{Establishment of Information Technology Support Center}

To accelerate the widespread use of personal computers installed at all divisions, the Information Technology Support Center was established in response to the installation of main LAN for information system. The purpose of this Center is to provide the help function to the employees who are at a loss in the use of their personal computer. Namely, the Center offers the following services.

- Education of personal computer users in the steelworks in the method of use of basic PC software, word processor software, spreadsheet software, etc.

- Services and consulting regarding the daily use of personal computer through telephone, FAX and electric mail (Inquiry/Guidance)

- Technical support to divisional system managers (answer to technical problems in network interconnection)

The Information Technology Support Center has made a great contribution to the improvement of information technology literacy of the personal computer users and divisional system managers in the steelworks.

\subsection{Prompt production result reporting system (Example 1 of information system building)}

\section{(1) Purpose and background of development}

In the past, the "prompt production result report" was used to grasp the daily production activities at steelworks. Namely, the information written on paper was transmitted to related plants and divisions. Under this system, many hands and log time were required for transfer, re-entry, confirmation, communication, etc. of information, resulting in delay in the detection of problems.

To improve this situation, an environment was created in which the general superintendent and other top management of the steelworks can check daily production information first thing in the morning by utilizing the basic LAN for information system, thus establishing the foundation for promoting the shared use and re-use of information by a small number of managerial persons in the flat organization and for the early detection of problems so that the most effective action can be taken rapidly at the location where such action is really required.

(2) Outline of the system

The out line of the prompt production result reporting system is shown in Fig.3. 


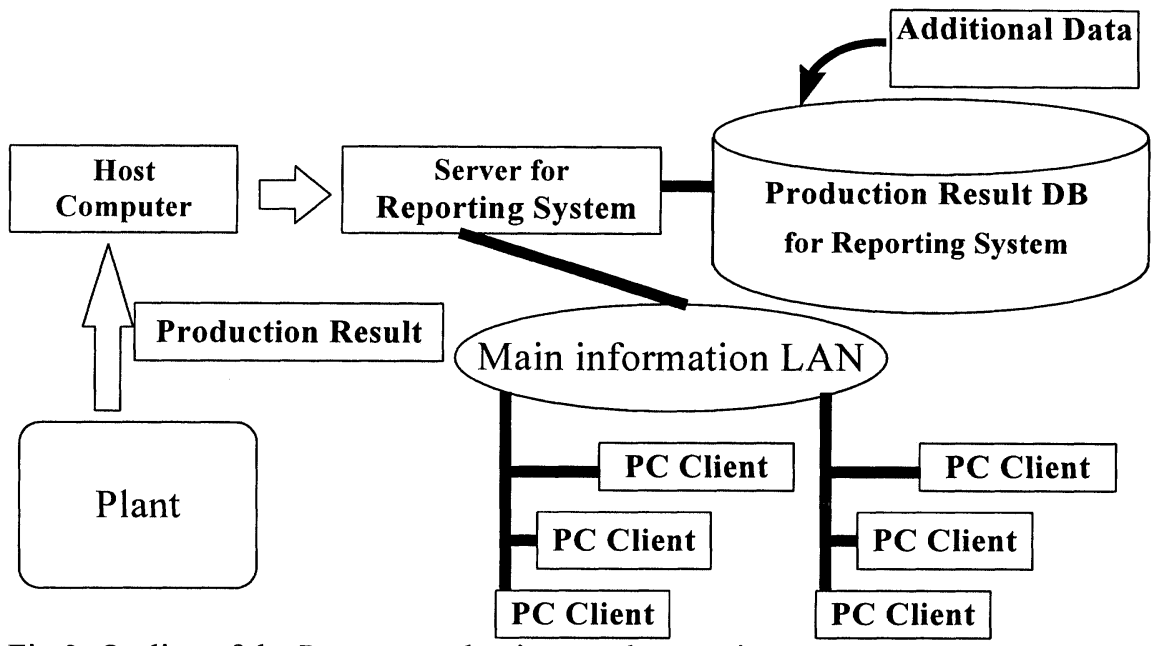

Fig.3 Outline of the Prompt production result reporting system

(3) Features of the system

The features of the system is shown in Fig. 4.

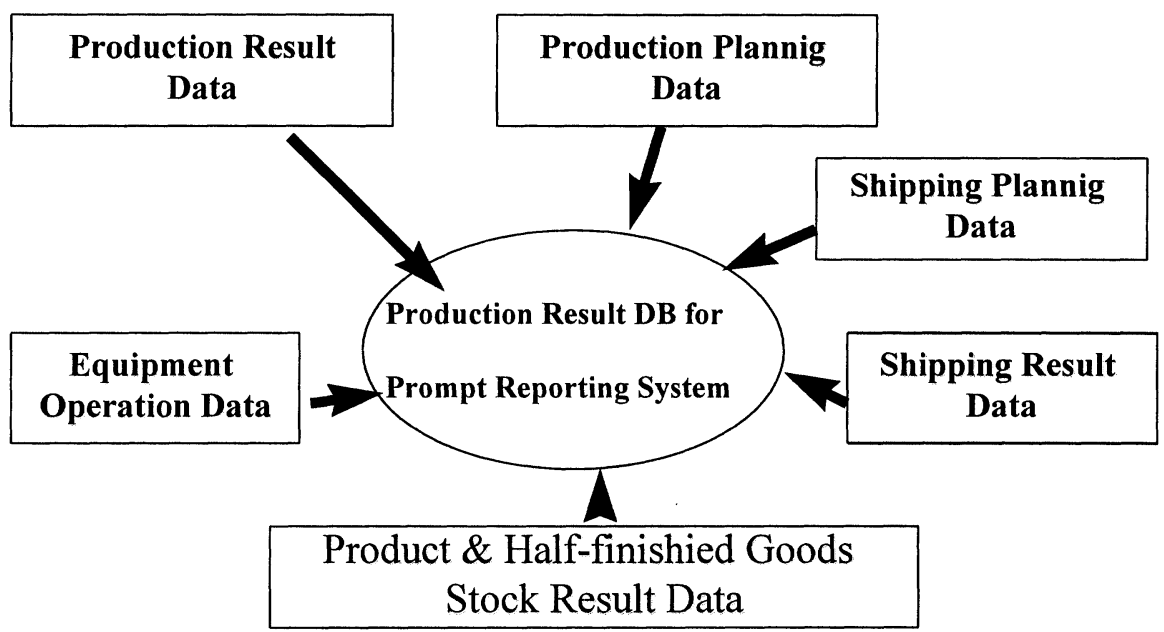

Fig.4 Available information by Prompt production result reporting system

\subsection{Decentralized type total production technology control system} (Example 2 of information system building)

(1) Purpose and background of development 
There are the following needs for the decentralized type production technology control system within the steelworks. (Goto , 1989 )(Yamazaki,1989):

Best method of use of total production technology control (SGK) data and process computer data to obtain the effects which offset the costs incurred in data collection. Obtaining new findings through multivariable analysis of correlations.

Transfer of technology and know-how, aiming at the reduction in the number of analysts to an elite corps and support to operation technology which is advancing day by day.

Shortening of the cycle required from the investigation of causes of quality troubles to the determination of appropriate counter-measures.

Further improvement of product quality.

(2) Outline of the system

The operation data is gathered into the database of the main frame for the collection and analysis of the information necessary for hypothesis and verification. The data is held for one to three years. Of these data, the data for the latest three months is transferred to the server of the division at regular intervals. Each staff extracts the data required for him and uses it for analysis. The configuration of the decentralized type total production technology control system is shown in Fig. 5

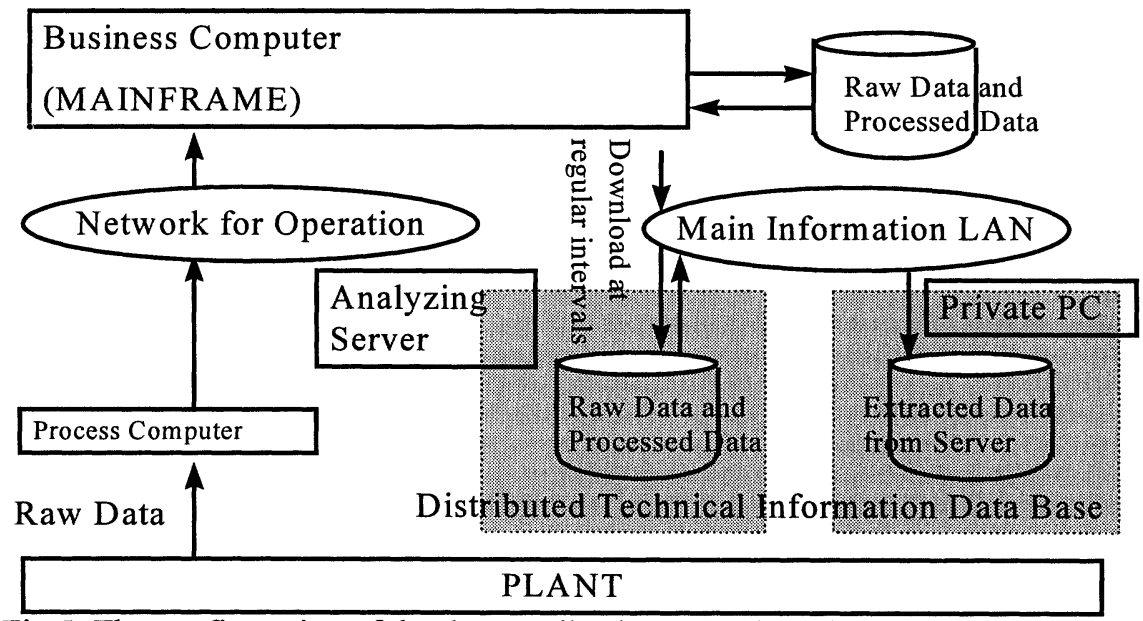

Fig.5 The configuration of the decentralized type total production technology control system

(3) Features of the system

The distributed RDB is used as the DB of analytical server. The personal computer for each employee is basically equipped with simple DB and spreadsheet software. If necessary, an integrated analytical software which enables mutlivariable analysis is equipped. 


\subsection{N-TCS (New Total Communication System) (Example 3 of information system building)}

(1) Purpose and background of development

The following are made possible by realizing the shared use of document information:

- Improvement of productivity of white-collar employees

- Transfer of document information

The background of development is as follows:

$1984 \sim$ : Installation of maintenance technology information control system

LAN for Maintenance Div., 15 terminals for exclusive use

$1992 \sim$ : Stepped up to TCS

LAN covering the whole steelworks, 45 terminals for exclusive use

$1997 \sim$ Stepped up to N-TCS

Shift to personal computer for OA

Utilization of multi-media document server system

(2) Outline of the system

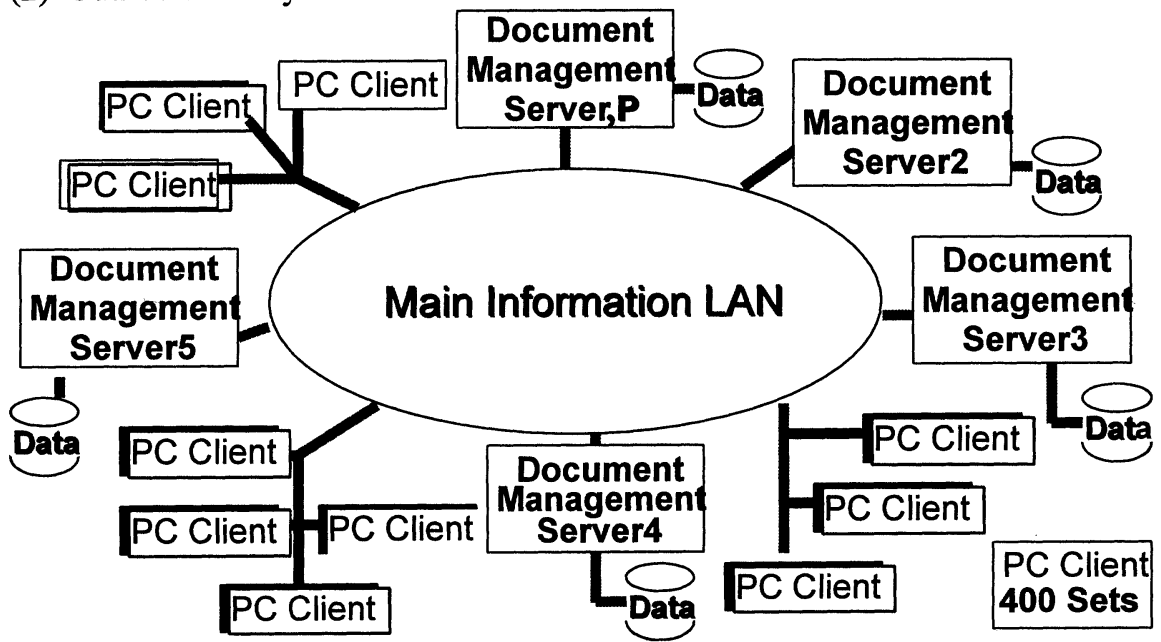

Fig.6 Outline of the N-TCS

(3) Features of the system

Various types of information can be handled by the same terminal.

Total number of documents catalogued: About 230,000, including about 60,000 technical documents and about 30,000 maintenance know-how documents Used for preparing work instructions at the plants (usable for 24 hours)

Examples of information that can be used by N-TCS are shown in Fig. 7.

Fig. 8 shows the co-ordinated type work flow in which the information shown in Fig. 7 is used. 


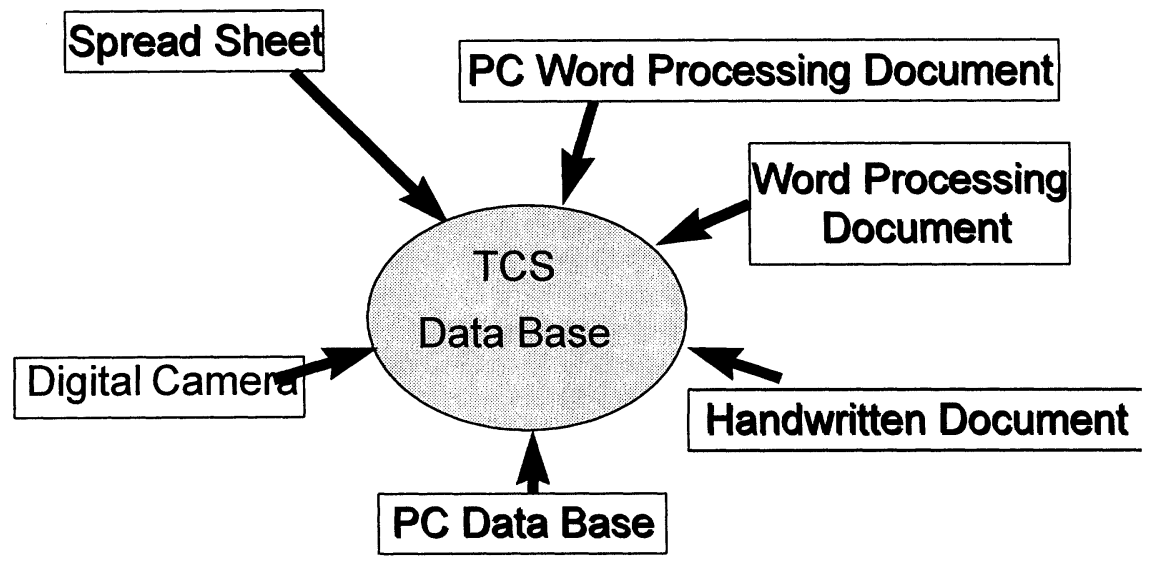

Fig.7 Examples of information that can be used by N-TCS

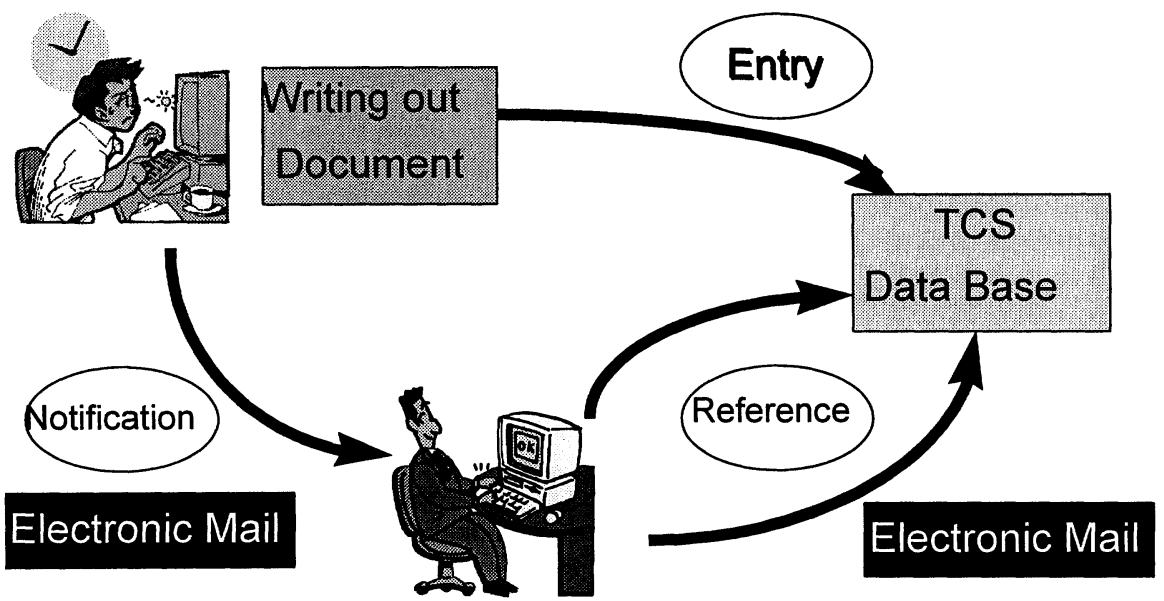

Fig.8 The co-ordinated type work flow

\subsection{Planning system for multiple lines (Example 4 of information system building)}

At Hirohata Works, the AI method was hitherto used for planning systems. In this method, the best solution was obtained out of multiple solutions by conducting simulation (Okinaka and Yamazaki 1989). Based on this philosophy, it is planned to create a hypothesis and verification type integrated system environment. For this planning, it is necessary to make a plan by multiple staff members. This planning system is an example of coordinated activity type groupware which is required for the future type organization (Nishigaki 1992). 
The method of preparing the production plan is described below. (See Fig. 9.)

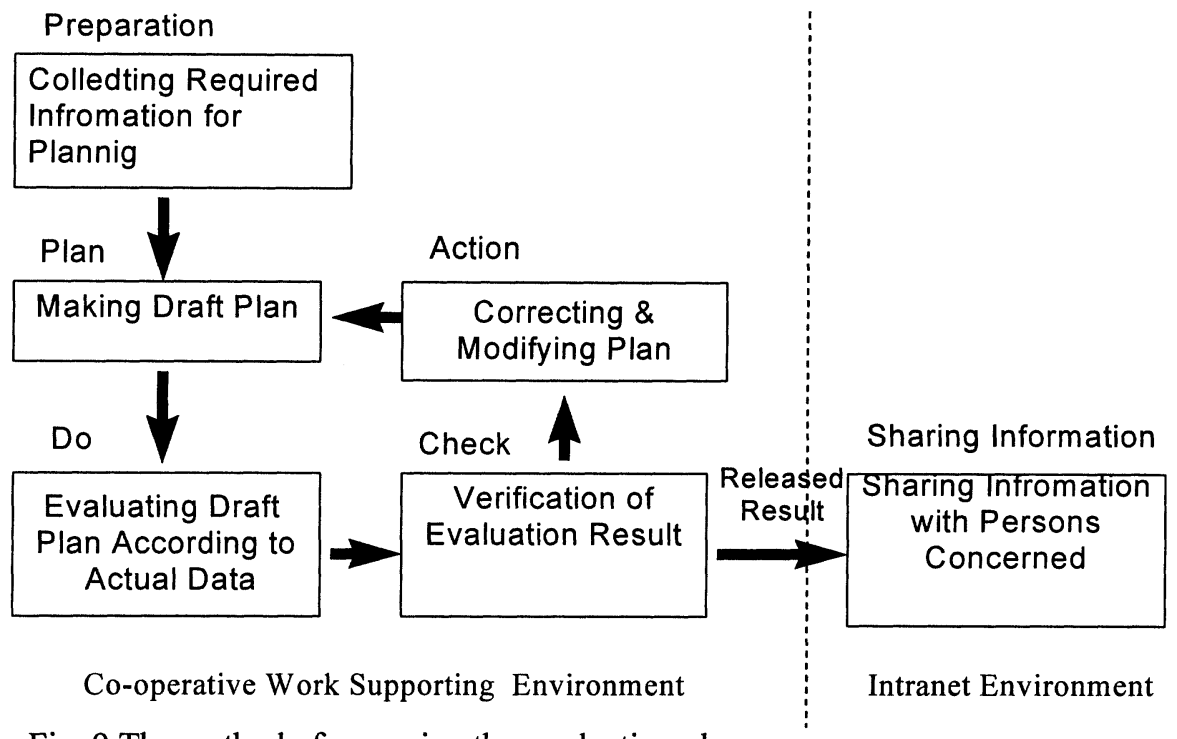

Fig. 9 The method of preparing the production plan

(1) A draft plan is prepared after collecting the required information. It is necessary to rotate the PDCA circle rapidly by evaluating the draft plan according to the actual data and correcting or modifying the plan based on the results of evaluation.

(2) For the determined results, it is important to release the information just in time so that all persons concerned can share the information.

Each main function in the preparation of production plan corresponds to each element of the PDCA circle. The formulation of production plan is one of hypothesis and verification type tasks.

The needs for each function and the information technology required for realizing such needs are summarized in Table 5 and 6, respectively.

And in order to realize this planning system, the managerial information LAN is fully utilized.

\section{CONCLUSION}

In view of user need diversification, it has hitherto been difficult to build an integrated information system in a well-controlled manner on the whole. Nippon Steel's Hirohata Works has succeeded in integrating the systems developed individually into a support system for improving the productivity of white-collar employees under a concept of "biological hypothesis and verification system". By utilizing systems proposed here, the productivity of 
white-collar employees has been increased so much. Compared to that in 10 years ago, the number of white-collar employees in 1998 is less than $40 \%$ in works. We should be very happy if our proposal is of reference to the persons concerned.

Table 5. The needs for each function required for realizing planning system for multiple lines

\begin{tabular}{|l|l|}
\hline & \multicolumn{1}{|c|}{ Needs for each Function } \\
\hline Preparation & $\begin{array}{l}\text { *Acquiring Proper Sound Data for Planning Production Plan } \\
\text { *Insurance of Flexibility in Viewing Information for Deciding } \\
\text { Production Plan Policy }\end{array}$ \\
\hline Plan & $\begin{array}{l}\text { *Making Clear Procedure of Production Plan and Telling Business } \\
\text { Knowledge from Generation to Generation }\end{array}$ \\
\hline Do & $\begin{array}{l}\text { *Calculating Accurate Evaluation Parameter of Production Plan in a } \\
\text { Short Time }\end{array}$ \\
\hline Check & *Verification of Plan According to Analytical View Point \\
\cline { 2 - 2 } & $\begin{array}{l}\text { *Understanding Problem in Common between Schedulars } \\
\text { *Forecasting Range and Level Affected by Revising Plan }\end{array}$ \\
\hline Action & $\begin{array}{l}\text { *At First Schedulars Revising Plan Independently and then } \\
\text { Coordinating on the Whole }\end{array}$ \\
\hline $\begin{array}{l}\text { Sharing Information with } \\
\text { Persons Concerned }\end{array}$ & $\begin{array}{l}\text { *Sharing Released Schedule Timely } \\
\text { *Showing Details if Necessary }\end{array}$ \\
\hline
\end{tabular}

Table 6. The information technology required for realizing planning system for multiple lines

\begin{tabular}{|l|l|}
\hline & \multicolumn{1}{|c|}{ Information Technology } \\
\hline Preparation & $\begin{array}{l}\text { *Constructing Data Base for Planning Production Plan } \\
\text { *Constructing Decision Support System by End-User Computing }\end{array}$ \\
\hline Plan & $\begin{array}{l}\text { *In Case of Planing Production Plan Manually->Visualizing } \\
\text { Production Plan Logic } \\
\text { *In Case of Planing Automatically } \\
\text {->Automatic Planing System Using Artificial Intelligence and } \\
\text { Genetic Algorithm }\end{array}$ \\
\hline Do & "Development of Real Time Simulation Algorithm \\
\hline Check & $\begin{array}{l}\text { *Constructing Environment for Analyzing Simulation Result by } \\
\text { End-User Computing }\end{array}$ \\
\hline & $\begin{array}{l}\text { *Showing Schedule Visually } \\
\text { *Development of Sensitivity Analysis Model }\end{array}$ \\
\hline Action & *Development of Computer Supported Cooperative Work \\
\hline $\begin{array}{l}\text { Sharing Information with } \\
\text { Persons Concerned }\end{array}$ & *Equipment of Intranet Environnment \\
\hline
\end{tabular}




\section{REFERENCES}

M. Ito and H. Furukawa: "Current Status and Future Trends of CIM in the Japanese Steel Industry", Journal of Systems Integration, Vol. 2, No. 1, 1992, pp. $91 \sim 114$

H. Furukawa: Business Systems, Nippon Steel's Technical Bulletin, No. 341, 1991, pp. $38 \sim 44$

J. Osada: Problems in the Management of Steel Industry and Future Courses of Information Strategy, 31st Shiraishi Memorial Lecture, Japan Iron \& Steel Institute, Highly Information-Oriented Society and Steel Industry, 1995, pp. 13 $\sim 25$

T. Hiranuma: "Management Revolution" in the Integrated Iron and Steel Industry, Economic World Review (Nomura Research Institute), 1995, 10, 10, 1995, pp. $2 \sim 41$

H. Shimizu: Recapturing of Life, Chuo Koron Paperback Pocket Edition, 503, Enlarged edition, 1990

T. Ito and K. Saka: A Book for Changing Companies into Gifted Companies by Re-engineering. Ohm Publishing Company, 1995

Goto, Hariya, Akashi, Yoshitake and Nakawatari: Total Production Technology Control System for Materializing Technological Strategic Concepts, Hitachi Review, Vol. 71, No. 2, 1989, pp. $79 \sim 83$

T. Yamazaki: Technology Information System in which End User Computing is Firmly Established, Business Management, Vol. 26, No. 6, pp. $94 \sim 98$

I. Okinaka and T. Yamazaki: Application of AI Method to Production Planning System in the Steel Industry, Material for the 5th Software Study Meeting held by the Japan Software Science Society, 1989

T. Nishigaki(Ed.): Organization and Groupware, NTT Publishing Company, 1992

\section{BIOGRAPHY}

Hiroshi Morihisa received his BE and ME degree from Tokyo University in 1978 and 1980, respectively. Since 1980, he has been a systems engineer at the Nippon steel corporation and Nippon Steel information \& communication systems Inc.(ENICOM).

Currently, he is also a Ph.D. student of the Department of Information Systems Engineering, Faculty of Engineering, Osaka University. His research interest is business information systems planning. $\mathrm{He}$ is a member of the Institute of Electrical Engineers in Japan and Information Processing Society of Japan.

Hideo Ikeda received his BE and ME degree from Kyoto University in 1979 and 1981 , respectively. Since 1981, he has been a systems engineer at the Nippon steel corporation and Nippon Steel information \& communication systems Inc.(ENICOM). 
Hideki Uchibori received his BE and ME degree from Tokyo University in 1979 and 1981, respectively. Since 1981, he has been a systems engineer at the Nippon steel corporation and Nippon Steel information \& communication systems Inc.(ENICOM).

Ryota Oshita received his BE and ME degree from Kobe University in 1983 and 1985 , respectively. Since 1985 , he has been a systems engineer at the Nippon steel corporation and Nippon Steel information \& communication systems Inc.(ENICOM).

Norihisa Komoda received his $\mathrm{BE}, \mathrm{ME}$, and $\mathrm{Ph} . \mathrm{D}$ degrees from Osaka University in 1972, 1974, and 1982, respectively. He is currently a professor at the Department of Information Systems Engineering, Faculty of Engineering, Osaka University. He had been a researcher of Systems Development Laboratory at Hitachi co. Itd. He stayed at the University of California, Los Angeles as a visiting researcher from 1981 to 1982 .His research interests include systems engineering and knowledge informations processing. He is a member of the IEEE, the ACM, the institute of Electrical Engineers in Japan, and the Society of Instrument and Control Engineering. He received the Awards for outstanding paper and the Awards for outstanding technology both from the Society of Instrument and Control Engineering. 